\title{
Effects of applying Lactobacillus helveticus H9 as adjunct starter culture in yogurt fermentation and storage
}

\author{
Tingting Zhou, ${ }^{1,2}$ Rui Huo, ${ }^{1,2}$ Lai-Yu Kwok, ${ }^{1,2}$ Changkun Li, ${ }^{1,2}$ Yuzhu Ma, ${ }^{1,2}$ Zhihui Mi, $^{1,2}$ and Yongfu Chen ${ }^{1,2 *}$ \\ ${ }^{1}$ Key Laboratory of Dairy Biotechnology and Engineering, and \\ ${ }^{2}$ Key Laboratory of Dairy Products Processing, Ministry of Education P. R. C., Inner Mongolia Agricultural University, Huhhot 010018, P. R. China
}

\begin{abstract}
Lactobacillus helveticus $\mathrm{H} 9$ is a probiotic bacterium originating from traditional Tibetan kurut. It has high angiotensin-converting enzyme-inhibitory (ACEI) and antihypertensive activities. We aimed to evaluate the effects of $L$. helveticus H9 supplementation in yogurt fermentation and storage. We monitored changes of multiple parameters over $28 \mathrm{~d}$ of storage at $4^{\circ} \mathrm{C}$; namely, $\mathrm{pH}$, titratable acidity, free amino groups, ACEI activity, physical properties, volatile flavor compounds, and sensory quality. Supplementation of L. helveticus H9 enhanced fermented milk acidification and proteolysis, resulting in a shorter fermentation time. The H9 treatment significantly increased the ACEI activity of the fermented milks. Fifteen key volatile flavors were detected by solid-phase microextraction-gas chromatography-mass spectrometry across all samples. More alcohols, aldehydes, and nitrogenous compounds, especially acetoin and benzaldehyde, were detected in the H9-supplemented fermented milks. The human sensory scores for flavor and texture, but not appearance, were lower for the H9-supplemented fermented milks, particularly beyond 2 wk of cold storage. Our results will be of interest to the dairy industry for developing novel functional dairy products.

Key words: Lactobacillus helveticus H9, fermented milk, angiotensin-converting enzyme (ACE)-inhibitory activity, sensory property
\end{abstract}

\section{INTRODUCTION}

Probiotics are "living microorganisms, which promote beneficial health effects for the host if administered in adequate amounts" (FAO/WHO, 2002). The consumption of probiotic fermented milk can confer numerous desirable functions to the host; for example, boosting

Received February 16, 2018.

Accepted September 4, 2018.

*Corresponding author: nmgyfchen@126.com the immune system, modulating intestinal microbiota (Li et al., 2017), alleviating hypertension (Seppo et al., 2003; El-Fattah et al., 2016), and reducing Helicobacter pylori loads in infected children (Yang and Sheu, 2012).

Lactobacillus helveticus is generally recognized as safe (GRAS), and it is used as a starter culture in manufacturing semi-hard cheeses and fermented milk products (Griffiths and Tellez, 2013; Bian et al., 2016). Several probiotic L. helveticus strains are used as fermentation starters or food additives; for example, L. helveticus CP790 (Yamamoto et al., 1994; Maeno et al., 1996), L. helveticus LBK-16H (Seppo et al., 2002; Jauhiainen et al., 2005), and L. helveticus R0052 (Foster et al., 2011). These bacteria generally have high extracellular proteinase activities and thus release specific bioactive peptides during milk fermentation. Some of these peptides may inhibit the angiotensin-converting enzyme (ACE), a transmembrane zinc metallopeptidase that is related to hypertension (Seppo et al., 2003; Beermann and Hartung, 2013; Zoumpopoulou, 2016). Inhibiting $\mathrm{ACE}$ is an important strategy for controlling clinical hypertension (Hussain et al., 2018).

Lactobacillus helveticus H9 is a novel probiotic strain isolated from the traditional kurut from Tibet, China (Airidengcaicike et al., 2010). Fermented milks produced with L. helveticus H9 possess excellent ACE-inhibitory (ACEI) activity with high levels of antihypertensive peptides such as Val-Pro-Pro (VPP) and Ile-Pro-Pro (IPP; Chen et al., 2014a; Wang et al., 2015). Previous studies have shown that L. helveticus $\mathrm{H} 9$ is a reliable probiotic bacterium with a clear origin and genetic background. The genetic material of the H9 strain has been completely sequenced and mapped. However, microbial interactions between the H9 strain and conventional starter bacteria during the dairy fermentation process and post-fermentation cold storage have not been fully characterized. Thus, it is necessary to evaluate the stability of the fermented products and the effect of storage on the bioactive materials produced by L. helveticus $\mathrm{H} 9$ fermentation.

The application of probiotic bacteria in fermentation may increase the nutritional value of dairy products, but 
it could also alter the sensory characteristics (Damin et al., 2008; Li et al., 2014; Sfakianakis and Tzia, 2014). Lactobacillus helveticus is known to have high proteolytic activity (Nielsen et al., 2009; Ahtesh et al., 2017), and it has been used for milk fermentation. Moreover, the application of $L$. helveticus in functional fermented milk drinks has been reported to cause no significant differences in flavor, appearance, or consumer acceptance compared with the commercial product Yakult (Yakult Honsha, Tokyo, Japan; Ahtesh et al., 2017). Lactic acid bacteria are widely used in fermented milks because of their desirable sensory characteristics and potential health benefits. However, few studies have investigated the overall impact of the probiotic strains on product qualities, including flavor, texture, and probiotic characteristics, when used in adjunct with conventional starter bacteria during fermentation and product storage. Ideally, the selected probiotic strains should have minimal effect on the stability and sensory quality of the fermented products while retaining the beneficial properties; and these features should also be included as assessment parameters when choosing probiotic strains for large-scale industrial production (Tripathi and Giri, 2014).

Thus, the main objective of this work was to investigate the effects of L. helveticus $\mathrm{H} 9$ used in adjunct with commercial starter cultures on organic acid content, ACEI activity, and flavor and texture of fermented milk during $28 \mathrm{~d}$ of storage. The information obtained in this work should be of interest to the dairy industry, particularly concerning the development and application of novel probiotic strains in functional dairy foods.

\section{MATERIALS AND METHODS}

\section{Bacterial Strains}

Lactobacillus helveticus H9 was stored in skim milk medium at $-80^{\circ} \mathrm{C}$ in the Lactic Acid Bacteria Culture Collection (LABCC) of the Key Laboratory of Dairy Biotechnology and Engineering, Ministry of Education, Inner Mongolia Agricultural University, China. The bacteria were activated by subculturing twice in liquid de Man, Rogosa, and Sharpe (MRS) medium at $37^{\circ} \mathrm{C}$ for $24 \mathrm{~h}$. The commercial yogurt starter culture (YFL904), consisting of Streptococcus thermophilus and Lactobacillus delbrueckii ssp. bulgaricus, was obtained from Chr. Hansen Co. Ltd. (Hørsholm, Denmark) in direct vat set (DVS) form.

\section{Preparation of Fermented Milk}

The fermented milk was prepared based on the National Standard of the People's Republic of China
(2010; standard GB 19302-2010) and a previously published work (Wang et al., 2009). The reconstituted milk was prepared from $11.5 \%$ (wt/wt) whole milk powder (NZMP Co. Ltd., Wellington, New Zealand) (containing, per $100 \mathrm{~g}, 39.1 \mathrm{~g}$ of lactose, $26.8 \mathrm{~g}$ of fat, and $25.0 \mathrm{~g}$ of protein) with the addition of $6.5 \%$ sucrose. The whole milk powder and sucrose were blended with sterilized distilled water at $65^{\circ} \mathrm{C}$ and homogenized at $20 \mathrm{MPa}$ by using a high-pressure homogenizer ( $\mathrm{SRH}$, Shenlu, Shanghai) before pasteurization $\left(95^{\circ} \mathrm{C}\right.$ for 5 min). The reconstituted milk was cooled to $42^{\circ} \mathrm{C}$ and then inoculated with $0.03 \%$ (wt/vol) seed cultures. Five different types of seed cultures were used for the experiments: commercial yogurt starter YF-L904 alone or YF-L904 in combination with 4 different inoculum concentrations of L. helveticus H9 $\left(1 \times 10^{6}, 2 \times 10^{6}\right.$, $5 \times 10^{6}$, and $1 \times 10^{7} \mathrm{cfu} / \mathrm{mL}$ ). The inoculated milk samples were allowed to ferment at $42^{\circ} \mathrm{C}$ until reaching $\mathrm{pH}$ 4.5. Then, the finished fermented milks were cooled to $4^{\circ} \mathrm{C}$ in an ice bath and stored at $4^{\circ} \mathrm{C}$ for 28 d. Aliquots of samples were collected after 1, 7, 14, 21, and $28 \mathrm{~d}$ of storage. The fermentation experiment was performed in triplicate.

\section{Measurement of Fermentation Characteristics}

The $\mathrm{pH}$ was determined using a pHS-3E $\mathrm{pH}$ meter (Leici, Shanghai, China). Titratable acidity was measured by titration with $0.1 \mathrm{~mol} / \mathrm{L} \mathrm{NaOH}$ using phenolphthalein as indicator (National Standards of the People's Republic of China, 1996). The content of free amino groups was determined by the method described by Church et al. (1983).

\section{Determination of Organic Acids}

The amounts of organic acids (lactic, acetic, and citric acids) in the fermented milks were determined using HPLC (Agilent 1100; Agilent, Santa Clara, CA) according to the method of Scherer et al. (2012) with some modifications. Briefly, fermented milk samples (1 g) were mixed with $4 \mathrm{~g}$ of $1 \mathrm{~mol} / \mathrm{L} \mathrm{HCl}$, and the slurries were centrifuged for $10 \mathrm{~min}$ at $4,000 \times g$ at $4^{\circ} \mathrm{C}$. The supernatants were filtered using $0.22-\mu \mathrm{m}$ Millipore filters (Millipore Corp., Billerica, MA), and approximately $500-\mu \mathrm{L}$ aliquots from each sample were stored in HPLC vials at $-20^{\circ} \mathrm{C}$ until analysis. All samples were prepared and analyzed in triplicate. An HP 1100 series (Agilent) liquid chromatography equipped with degasser, quaternary pump, autosampler adjusted to $10-\mu \mathrm{L}$ volume injection, Zorbax SB-Aq C18 column (4.6 $\times 250 \mathrm{~mm}$, particle size $5 \mu \mathrm{m}$, Agilent), and a variable wavelength detector (VWD) was used. The column was eluted with $97 \%$ methanol (vol/vol) in the buffer solu- 
tion $(10 \mathrm{mmol} / \mathrm{L}$ PBS water, $\mathrm{pH} 2.5)$ at a flow rate of $0.5 \mathrm{~mL} / \mathrm{min}$ using an isocratic elution procedure with the column temperature set at $35^{\circ} \mathrm{C}$. The eluent was monitored at $210 \mathrm{~nm}$.

\section{Determination of ACEI Activity}

The ACEI activity was measured by HPLC (Agilent 1100; Wu et al., 2002; Chen et al., 2010). Briefly, each yogurt sample was centrifuged at $8,000 \times g$ for 10 min, and the supernatant was collected. The $\mathrm{pH}$ was adjusted to 8.3 , followed by high-speed centrifugation $(12,000 \times g)$ for $10 \mathrm{~min}$. The supernatant was used to determine the ACEI activity. Rabbit lung powder containing ACE and hippuryl-L-histidyl-L-leucine were obtained from Sigma Chemical Co. (St. Louis, MO). Both hippuryl-L-histidyl-L-leucine and ACE were separately dissolved in $100 \mathrm{~m} M$ Na-borate buffer ( $\mathrm{pH}$ 8.3) containing $300 \mathrm{mM} \mathrm{NaCl}$. Then, $50 \mu \mathrm{L}$ of supernatant sample $(\mathrm{pH} 8.3)$ and $50 \mu \mathrm{L}$ of hippuryl-L-histidyl-L-leucine (10 $\mathrm{mM}$ ) solution were mixed at $37^{\circ} \mathrm{C}$ for $2 \mathrm{~min} ; 50 \mu \mathrm{L}$ of ACE $(0.010 \mathrm{U} / \mathrm{mL})$ solution was added to the mixture and further incubated at $37^{\circ} \mathrm{C}$ for $40 \mathrm{~min}$. The reactant was placed in $85^{\circ} \mathrm{C}$ water bath for 10 min to inactivate the enzyme. Afterward, $200 \mu \mathrm{L}$ of EDTA disodium salt (EDTA $2 \mathrm{Na} ; 0.1 \mathrm{~mol} / \mathrm{L}$ ) was added to the system. The solution was filtered using a $0.22-\mu \mathrm{m}$ membrane filter, and $20 \mu \mathrm{L}$ of filter reactant was directly injected onto a Zorbax C18 column $(4.6 \times 250 \mathrm{~mm}$, particle size 5 $\mu \mathrm{m}$, Agilent). The column was eluted with $22 \%$ (vol/ vol) acetonitrile in deionized water (containing $0.1 \%$ trifluoroacetic acid) at a flow rate of $1.0 \mathrm{~mL} / \mathrm{min}$ using a pump, and the eluent was monitored at $228 \mathrm{~nm}$. The column temperature was controlled at $30^{\circ} \mathrm{C}$. The ACEI activity was calculated as follows: ACEI activity = $[(\mathrm{Cc}-\mathrm{Cs}) /(\mathrm{Cc}-\mathrm{Cb})] \times 100 \%$, where $\mathrm{Cc}, \mathrm{Cb}$, and $\mathrm{Cs}$ represented the concentrations of hippuric acid without the tested sample (control $=\mathrm{Cc}$ ), without ACE (blank $=\mathrm{Cb}$ ), and with both $\mathrm{ACE}$ and the tested sample $($ sample $=\mathrm{Cs})$, respectively.

\section{Quantification of ACEI Peptides and $y$-Aminobutyric Acid}

The fermented milk samples were centrifuged at $8,000 \times g$ for $10 \mathrm{~min}$, and the supernatants were added to acetonitrile at a ratio of 1:4 to remove protein. Supernatants were transferred and dried under vacuum before redissolving in $87 \%$ acetonitrile. The concentrations of VPP, IPP, and $\gamma$-aminobutyric acid (GABA) in the samples were determined with an ultra-performance liquid chromatography (UPLC) system (Waters, Manchester, UK) connected to a quadrupole time-offlight instrument (Q-Tof, Waters; Chen et al., 2010).
Forty microliters of each sample was injected onto the UPLC using an automatic injector (Waters Corp., Milford, MA). Peptides (VPP, IPP) were eluted with solvent A (formic acid $0.1 \%$ in water) and solvent $\mathrm{B}$ (0.1\% formic acid in acetonitrile) with the following gradient elution program: 0-3 min, $13-40 \% \mathrm{~B} ; 3-6 \mathrm{~min}$, 40-90\% B; 6-6.5 min, $90 \%$ B; $6.5-9$ min, $90-13 \%$ B; at a flow rate of $0.3 \mathrm{~mL} / \mathrm{min}$ through a $\mathrm{T} 3$ column $(2.1$ $\mathrm{mm} \times 100 \mathrm{~mm}$, particle size 5; i.e., $1.8 \mu \mathrm{m}$; Waters Corp.). The elution of GABA was achieved with an isocratic elution procedure at a flow rate of $0.45 \mathrm{~mL} /$ min. Results were acquired between the MS mass-tocharge $(\mathrm{m} / \mathrm{z})$ range from 100 to 700 with the following MS parameters: desolvation temperature $150^{\circ} \mathrm{C}$, source temperature $110^{\circ} \mathrm{C}$, cone voltage $30 \mathrm{~V}$, collision energy $6 \mathrm{eV}$, nitrogen desolvation gas flow rate of $600 \mathrm{~L} / \mathrm{h}$, and nebulizer flow rate of $50 \mathrm{~L} / \mathrm{h}$. The mass spectrometer was previously calibrated over a mass range of $m / z 100$ to 1500 using sodium formate solution. Leuencephalin $(2 \mathrm{ng} / \mathrm{mL}$ ) was infused at a rate of $10 \mu \mathrm{L} / \mathrm{min}$ to adjust data, generating an $[\mathrm{M}+\mathrm{H}]$ at $m / z 556.2771$. The concentrations of IPP, VPP, and GABA were determined by interpolating from the respective standard curves. A conventional Fmoc (fluorenylmethyloxycarbonyl) solidphase synthesis method with a $431 \mathrm{~A}$ peptide synthesizer (Applied Bio-Systems Inc., Darmstadt, Germany) was used to verify the purity of the synthesized peptides.

\section{Texture Profile Analysis}

Texture profile analysis (TPA) was determined by using the method described by Supavititpatana et al. (2008) with some modifications in the measurement conditions. The TPA included the full texture curve, hardness, cohesiveness, adhesiveness, springiness, resilience, gumminess, chewiness, and retentiveness. The collected data were analyzed by the TA-XT2 texture analyzer (Stable Micro Systems, Godalming, UK) and the flat bottom cylindrical probe type of SMS P/25 of $2.5 \mathrm{~cm}$ diameter. A speed of $5.0 \mathrm{~mm} / \mathrm{s}$ was used for the pre-test, and the test and post-test rates were run at $2 \mathrm{~mm} / \mathrm{s}$. The probe entered the fermented milk sample at a distance of $20 \mathrm{~mm}$ with an interval time of $5 \mathrm{~s}$ when the sample was compressed twice. The viscosity of fermented milk was determined with a viscometer (DVE, Brookfield, IL).

The syneresis of fermented milk was measured based on Wu et al. (2000). A qualitative filter paper (medium speed, diameter $11 \mathrm{~cm}$; Aoke Filter Paper Factory, Jiangsu, China) was fitted into a funnel. Each fermented milk sample (15 g) was added onto the funnel and allowed to stand for $1.5 \mathrm{~h}$ at $21^{\circ} \mathrm{C}$. The syneresis percentage was calculated as the weight of filtrate divided by the initial weight $\times 100$. 


\section{Analysis of Volatile Flavor Compounds}

Volatile flavor compounds present in the fermented milk samples were identified by GC-MS (7697-GC7980-MS-5977, Agilent) according to Pan et al. (2014). Based on the sensitivity toward both polar and aromatic compounds, a divinylbenzene/carboxen/polydimethylsilaxane fiber (DVB/CAR/PDMS, 50/30 $\mu \mathrm{m}$ ) was selected and instilled in a solid-phase microextraction (SPME) manual holder (Supelco, Bellefonte, PA). Five grams of sample was placed in a $10-\mathrm{mL}$ sample vial sealed with a polytetrafluoroethylene septum. The septum was inserted with the SPME needle and placed in the SPME instrument for $60 \mathrm{~min}$ at $50^{\circ} \mathrm{C}, 300 \mathrm{rpm}$. The fiber was pierced into the gas chromatograph immediately and desorbed at $250^{\circ} \mathrm{C}$ for $3 \mathrm{~min}$. Volatile compounds absorbed onto the SPME fiber were passed through an HP-5MS column (30 m length, $0.25 \mathrm{~mm}$ inside diameter, $0.25 \mu \mathrm{m}$ film thickness; Agilent) with helium as the carrier gas delivered at $1 \mathrm{~mL} / \mathrm{min}$. The $\mathrm{GC}$ oven temperature program was set at $35^{\circ} \mathrm{C}$ for 5 min and increased from $35^{\circ} \mathrm{C}$ to $140^{\circ} \mathrm{C}$ at a rate of $5^{\circ} \mathrm{C} /$ min for $2 \mathrm{~min}$, followed by an increase to $250^{\circ} \mathrm{C}\left(10^{\circ} \mathrm{C} /\right.$ $\mathrm{min}$ ) for $3 \mathrm{~min}$. The GC-MS analysis was performed as described by the National Institute of Standards and Technology (NIST) 1.1 database (https://www.nist .gov/srd/nist-standard-reference-database-1a-v14) to identify the compounds. Mass spectra were collected in electronization mode with an electron ionization source. The electron energy was $70 \mathrm{eV}$, with the emission current of $100 \mu \mathrm{A}$ and an ion source temperature of $230^{\circ} \mathrm{C}$. The mass range was set at 33 to $450 \mathrm{~m} / z$. The results were qualitative and described as retention time and relative peak area. Each measurement was repeated 3 times.

\section{Human Sensory Evaluation}

A sensory analysis was applied to evaluate the sensory quality of the fermented milks (Barrantes et al., 1994; Bayarri et al., 2011). Twenty trained panelists were invited and asked to score the flavor, texture, and appearance of samples using a 9-point intensity scale ( 1 = disliked extremely; $9=$ liked extremely). Participants were guided to taste fermented milks and drink water between samples to cleanse the palate. Scores were shown as mean \pm standard deviations (SD).

\section{Statistical Analysis}

All data were expressed as mean \pm SD. Differences between groups were analyzed by ANOVA or multivariate ANOVA (MANOVA) using SPSS Base 19.0
(IBM Ltd., New York, NY). Principal component analysis (PCA) plots and other figures were created by using the OriginPro 2015 software (OriginLab Co., Northampton, MA).

\section{RESULTS}

\section{Fermentation Time}

The fermentation time required for the fermented milks to reach an endpoint of $\mathrm{pH} 4.5$ is shown in Supplemental Table S1 (https://doi.org/10.3168/jds.2018 -14602). An increase in inoculum of L. helveticus H9 significantly reduced the milk fermentation time $(P<$ 0.05 ) from $5.00 \pm 0.01 \mathrm{~h}$ (control, no L. helveticus H9) to the shortest fermentation time of $3.75 \pm 0.01 \mathrm{~h}$ with an inoculum of $1 \times 10^{7} \mathrm{cfu} / \mathrm{mL}$.

\section{Changes in Titratable Acidity, $\mathrm{pH}$, and Level of a-Amino Groups During Cold Storage}

The main indicators for yogurt acidity evaluation are $\mathrm{pH}$ and titratable acidity. The post-acidification of the control milk produced solely with the commercial starter was mild. Supplementation with L. helveticus H9 significantly enhanced post-acidification during cold storage, as indicated by the decrease in $\mathrm{pH}$ and increase in titratable acidity of fermented milks $(P<$ 0.05; Figure 1). The differences were more obvious with prolongation of storage and the use of a larger inoculum of L. helveticus $\mathrm{H} 9$.

The level of $\alpha$-amino groups in each of the fermented milks was stable throughout storage and was lower in milks fermented with L. helveticus H9 (Figure 2). The concentration of $\alpha$-amino groups generally increased with inoculum of L. helveticus H9. For example, at d 1 of storage, the $\alpha$-amino group content detected in fermented milks produced with a low level of $L$. helveticus H9 $\left(1 \times 10^{6} \mathrm{cfu} / \mathrm{mL}\right)$ and those with $1 \times 10^{7} \mathrm{cfu} / \mathrm{mL}$ L. helveticus $\mathrm{H} 9$ was $3.26 \pm 0.24$ and $6.77 \pm 0.45 \mathrm{mM}$ $(P<0.05)$.

\section{Changes in Lactate, Acetate, and Citrate Concentrations During Cold Storage}

The fermented milk concentrations of lactate, acetate, and citrate are summarized in Figure 3. No obvious difference was found between the lactate concentration of the control and H9-supplemented fermented milks (inoculum of $\left.1 \times 10^{6} \mathrm{cfu} / \mathrm{mL} ; P>0.05\right)$ during the $28 \mathrm{~d}$ of storage (from $8.25 \pm 0.88$ to $8.69 \pm 0.20 \mathrm{~g} / \mathrm{L}$ and from $10.01 \pm 0.68$ to $11.25 \pm 0.60 \mathrm{~g} / \mathrm{L}$, respectively). Adding L. helveticus $\mathrm{H} 9$ significantly increased $(P<0.05)$ the 
lactate content (compared with the control), although it was not significantly affected by the inoculum of $L$. helveticus H9 ( $P>0.05$; Figure 3a). The concentrations of acetate and citrate in all fermented milk groups fluctuated during storage except at the highest inoculum of L. helveticus $\mathrm{H} 9\left(1 \times 10^{7} \mathrm{cfu} / \mathrm{mL}, P<0.05\right)$. However, adding $L$. helveticus $\mathrm{H} 9$ generally increased acetic acid and decreased citric acid concentration (Figure 3b, 3c). The concentrations of both acetate $(0.14 \pm 0.01$ to 0.17 $\pm 0.02 \mathrm{~g} / \mathrm{L})$ and citrate $(0.24 \pm 0.01$ to $0.30 \pm 0.02$ $\mathrm{g} / \mathrm{L})$ remained stable throughout the storage period $(P$ $>0.05)$ when a high inoculum of L. helveticus H9 $(1 \times$ $10^{7} \mathrm{cfu} / \mathrm{mL}$ ) was used.

\section{Changes in ACEl Activity and Concentrations of VPP, IPP, and GABA During Cold Storage}

The fermented milk ACEI and concentrations of VPP, IPP, and GABA are shown in Table 1. The range of ACEI of the control (fermented solely by commercial starter) was $3.10 \pm 0.11$ to $46.61 \pm 1.11 \%$ during the storage period, whereas it ranged from $28.49 \pm 0.45$ to $78.28 \pm 1.54 \%$ for the L. helveticus H9-supplemented fermented milks. Prolonged cold storage of the fermented milks led to a significant increase $(P<0.05)$ in ACEI in both the control and H9-supplemented fermented milks. The highest ACEI $(78.28 \pm 1.54 \%)$ was detected after $14 \mathrm{~d}$ of storage in samples with the highest inoculum of L. helveticus H9. Moreover, positive correlations were observed between the fermented milk ACEI and VPP and IPP contents $(\mathrm{r}=0.74$ and 0.78 , respectively; Figure 4 ). The highest VPP and IPP contents $(1.89 \pm 0.18$ and $1.64 \pm 0.10 \mu \mathrm{mol} / \mathrm{L}$, respectively) were detected in $\mathrm{H} 9$-supplemented fermented milk samples (inoculum of $1 \times 10^{7} \mathrm{cfu} / \mathrm{mL}$ ) after 28 and $1 \mathrm{~d}$ of cold storage, respectively. In contrast, VPP and IPP were not detectable in fermented milks produced solely with the commercial starter. The level of

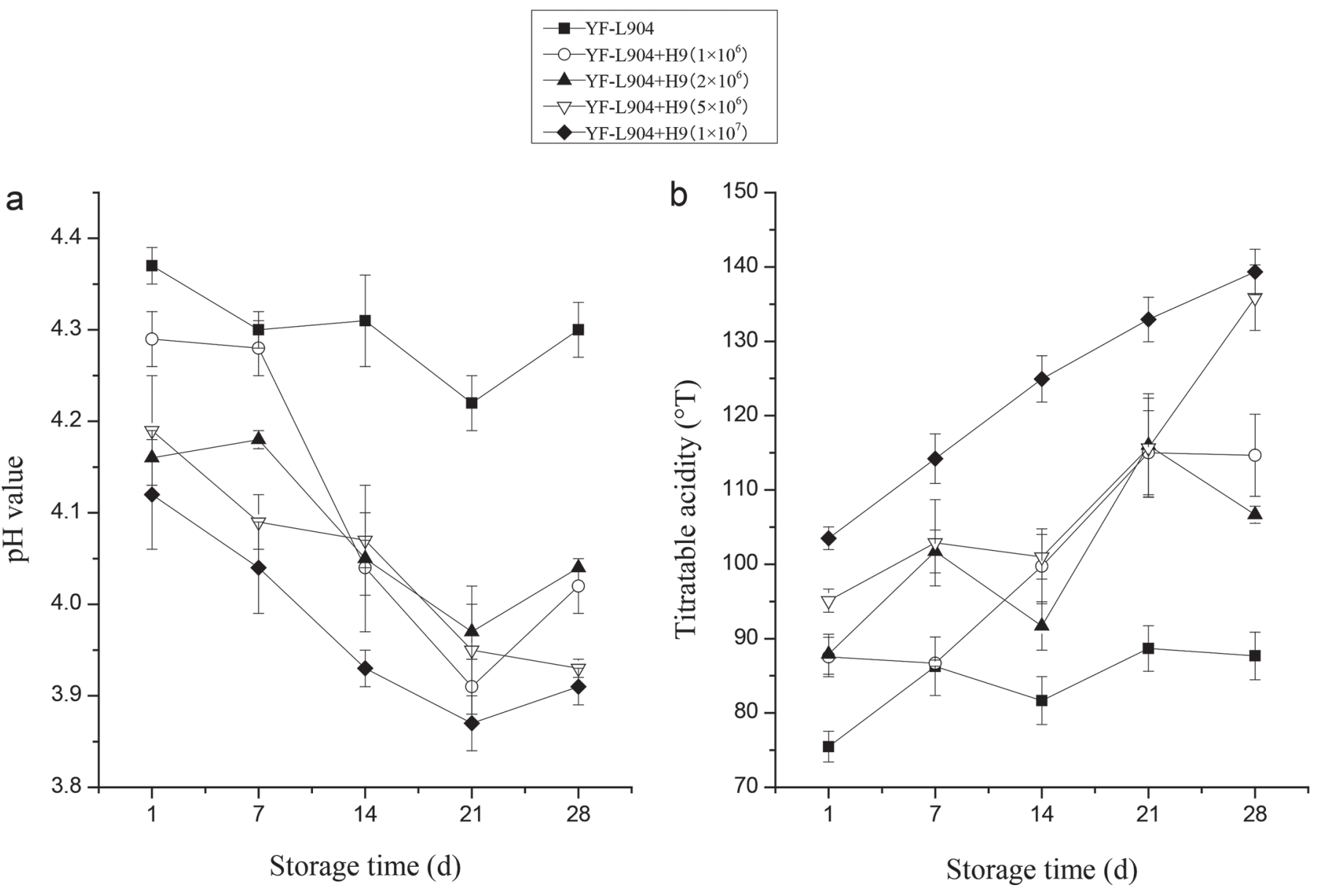

Figure 1. Effect of Lactobacillus helveticus H9 inoculum size on the post-acidification of fermented milks during cold storage measured as (a) $\mathrm{pH}$ and (b) titratable acidity $\left({ }^{\circ} \mathrm{T}=\right.$ degrees Theurer). YF-L904 $=$ commercial yogurt starter culture, consisting of Streptococcus thermophilus and L. delbrueckii ssp. bulgaricus. Error bars represent SD. 


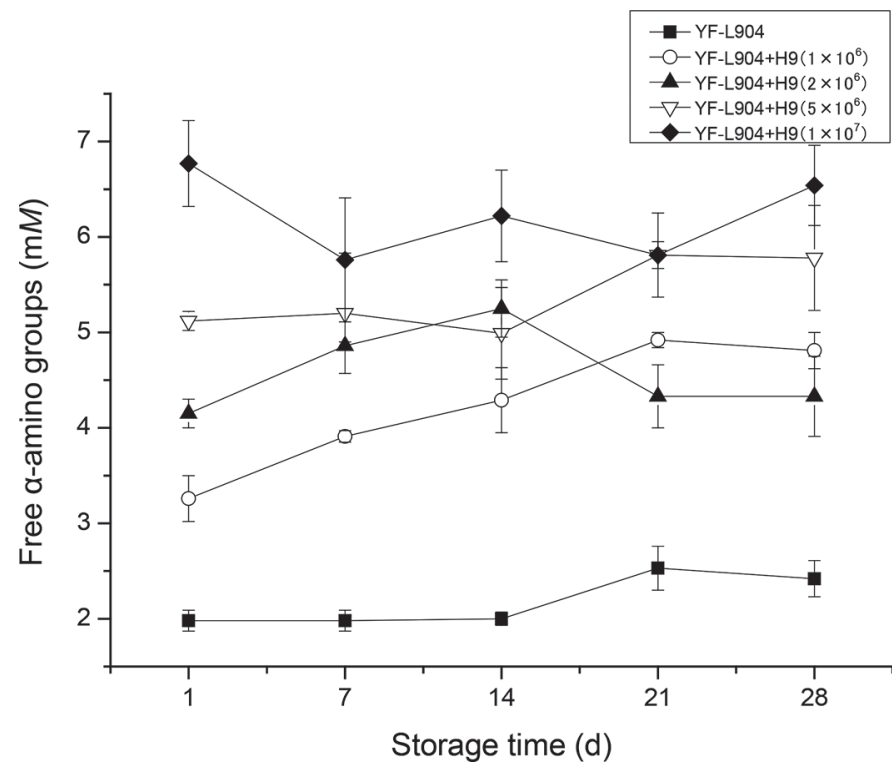

Figure 2. Effect of Lactobacillus helveticus H9 inoculum size on the concentration of free $\alpha$-amino groups of fermented milks during cold storage. YF-L904 = commercial yogurt starter culture, consisting of Streptococcus thermophilus and L. delbrueckii ssp. bulgaricus. Error bars represent SD.

GABA correlated only mildly with ACEI $(\mathrm{r}=0.307)$. The L. helveticus H9 inoculum size did not significantly influence the fermented milk GABA level $(P>0.05)$.

\section{Changes in Fermented Milk TPA During Cold Storage}

The texture profile was represented by 9 parameters: syneresis, hardness, cohesiveness, adhesiveness, springiness, gumminess, chewiness, resilience, and viscosity. Changes in the texture profile of fermented milk samples were evaluated by PCA and MANOVA (Figure 5). Figure 5a shows the PCA score plot of TPA of samples produced by using different starter bacteria. The first 2 principal components ( $\mathrm{PC} 1$ and $\mathrm{PC} 2$ ) contributed 98.90 and $1.10 \%$ of the total variance, respectively. Symbols representing the texture profile of YF-L904-fermented milks were not obviously separated from those of the L. helveticus H9-containing groups (Figure 5a); and no significant difference was detected between different groups, as confirmed by MANOVA $(P>0.05$; Figure $5 \mathrm{c})$. Viscosity correlated most with $\mathrm{PC} 1$, whereas resilience strongly correlated with PC2. The factor loadings also revealed strong correlations for fermented milk texture with viscosity and resilience. The resilience and viscosity of fermented milk samples increased during the first $14 \mathrm{~d}$ of storage and decreased thereafter. However, overall, addition of $L$. helveticus H9 did not seem to significantly influence fermented milk texture.
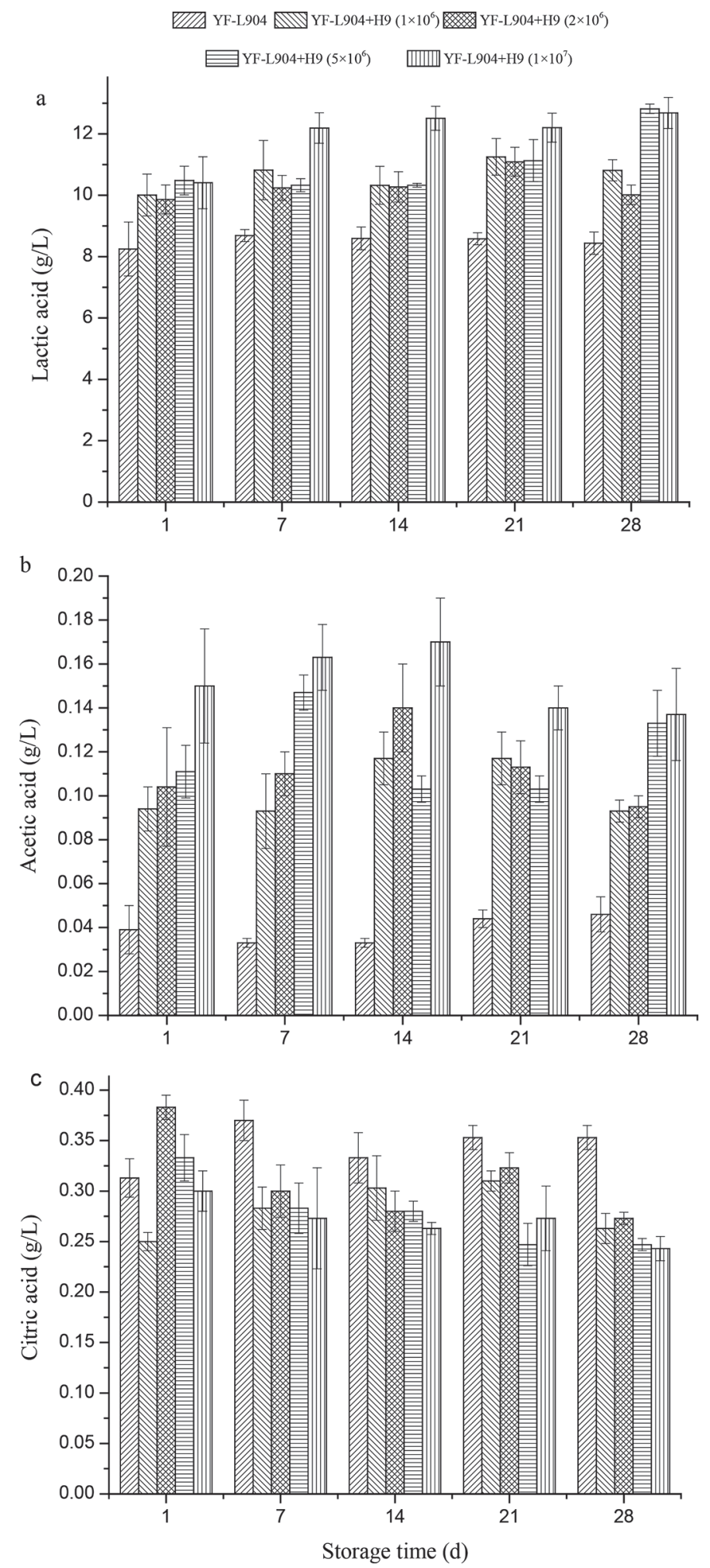

Figure 3. Effect of Lactobacillus helveticus H9 inoculum size on organic acid contents in fermented milks during cold storage. YF-L904 = commercial yogurt starter culture, consisting of Streptococcus thermophilus and L. delbrueckii ssp. bulgaricus. Error bars represent SD. 


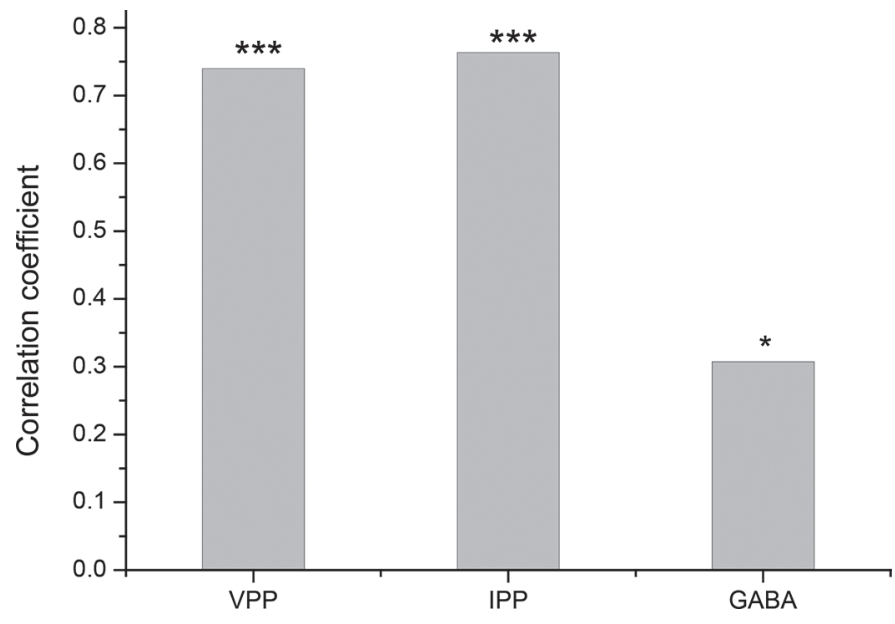

Figure 4. Pearson correlations between angiotensin-converting enzyme-inhibitory activity and levels of Val-Pro-Pro (VPP), Ile-Pro-Pro (IPP), and $\gamma$-aminobutyric acid (GABA) in the fermented milks. ${ }^{*} P<$ 0.05 and ${ }^{* * *} P<0.001$ represent significant correlations.

When the texture profiles of fermented milk samples were grouped based on storage time on the PCA score plot (Figure 5b), no significant difference was observed between sample groups at all time points $(P<0.05)$ except those at d 28, as supported by MANOVA (Figure 5d). Furthermore, no significant change was detected in the texture profile of $L$. helveticus H9-containing samples throughout storage $(P>0.05)$.

\section{Changes in Volatile Flavor Compounds Profile During Cold Storage}

The volatile flavor compounds of fermented milk were identified by using SPME-GC-MS. Our work identified a total of 103 volatile compounds among all L. helveticus H9-containing fermented milks, including 19 alcohols, 17 aldehydes, 13 ketones, 9 acids, 7 esters, 14 nitrogenous compounds, 6 aromatic compounds, and 18 other compounds. In contrast, only 58 volatile compounds (including 7 alcohols, 7 aldehydes, 11 ketones, 6 acids, 5 esters, 12 nitrogenous compounds, 5 aromatic compounds, and 5 other compounds) were detected in the fermented milks produced solely with the commercial starter. The H9-containing fermented milks possessed unique flavor compounds such as butanoic acid, 3-methylhexadecanoic acid, n-decanoic acid, propylene glycol, 1-hexanol, succindialdehyde, 2,3-butanedione, methyl isobutyl ketone, benzaldehyde, formic acid heptyl ester, delta-nonalactone, hexanediamide, $N, N^{\prime}-$ di-benzoyloxy, and some related derivatives. A total of

Table 1. Effect of cold storage on the angiotensin-converting enzyme-inhibitory (ACEI) activity and concentrations of Val-Pro-Pro (VPP), IlePro-Pro (IPP), and $\gamma$-aminobutyric acid (GABA) of fermented milks

\begin{tabular}{|c|c|c|c|c|c|}
\hline Time & Sample $^{1}$ (inoculum, cfu/mL) & ACEI (\%) & $\operatorname{VPP}(\mu \mathrm{mol} / \mathrm{L})$ & $\operatorname{IPP}(\mu \mathrm{mol} / \mathrm{L})$ & GABA (mg/L) \\
\hline \multirow[t]{5}{*}{$1 \mathrm{~d}$} & YF-L904 & $3.10 \pm 0.77^{\mathrm{d}, \mathrm{D}}$ & $\mathrm{ND}^{2}$ & ND & $57.17 \pm 0.56^{\mathrm{a}, \mathrm{C}}$ \\
\hline & YF-L904+H9 $\left(1 \times 10^{6}\right)$ & $39.72 \pm 0.56^{\mathrm{b}, \mathrm{B}}$ & $0.24 \pm 0.02^{\mathrm{d}, \mathrm{B}}$ & $0.27 \pm 0.06^{\mathrm{c}, \mathrm{B}}$ & $51.41 \pm 0.56^{\mathrm{b}, \mathrm{D}}$ \\
\hline & YF-L904+H9 $\left(2 \times 10^{6}\right)$ & $28.49 \pm 0.45^{\mathrm{c}, \mathrm{B}}$ & $0.26 \pm 0.08^{\mathrm{c}, \mathrm{B}}$ & $0.28 \pm 0.04^{\mathrm{c}, \mathrm{B}}$ & $45.31 \pm 1.68^{\mathrm{c}, \mathrm{C}}$ \\
\hline & YF-L904+H9 $\left(5 \times 10^{6}\right)$ & $66.09 \pm 7.42^{\mathrm{a}, \mathrm{B}}$ & $0.69 \pm 0.04^{\mathrm{a}, \mathrm{BC}}$ & $0.84 \pm 0.08^{\mathrm{a}, \mathrm{BC}}$ & $58.11 \pm 3.33^{\mathrm{a}, \mathrm{C}}$ \\
\hline & YF-L904+H9 $\left(1 \times 10^{7}\right)$ & $70.47 \pm 6.29^{\mathrm{a}, \mathrm{C}}$ & $1.27 \pm 0.06^{\mathrm{b}, \mathrm{C}}$ & $1.64 \pm 0.10^{\mathrm{b}, \mathrm{A}}$ & $56.51 \pm 0.02^{\mathrm{a}, \mathrm{B}}$ \\
\hline \multirow[t]{5}{*}{$7 \mathrm{~d}$} & YF-L904 & $19.03 \pm 3.13^{\mathrm{e}, \mathrm{C}}$ & ND & ND & $64.02 \pm 4.63^{\mathrm{a}, \mathrm{B}}$ \\
\hline & YF-L904+H9 $\left(1 \times 10^{6}\right)$ & $50.88 \pm 2.33^{\mathrm{c}, \mathrm{AB}}$ & $0.48 \pm 0.04^{\mathrm{b}, \mathrm{A}}$ & $0.63 \pm 0.08^{\mathrm{c}, \mathrm{A}}$ & $56.77 \pm 2.14^{\mathrm{b}, \mathrm{C}}$ \\
\hline & YF-L904+H9 $\left(2 \times 10^{6}\right)$ & $41.34 \pm 4.96^{\mathrm{d}, \mathrm{AB}}$ & $0.69 \pm 0.22^{\mathrm{bA}}$ & $0.74 \pm 0.01^{\mathrm{bc}, \mathrm{A}}$ & $48.64 \pm 1.00^{\mathrm{c}, \mathrm{BC}}$ \\
\hline & YF-L904+H9 $\left(5 \times 10^{6}\right)$ & $62.86 \pm 1.24^{\mathrm{b}, \mathrm{B}}$ & $0.85 \pm 0.20^{\mathrm{b}, \mathrm{B}}$ & $1.07 \pm 0.06^{\mathrm{b}, \mathrm{AB}}$ & $64.98 \pm 4.19^{\mathrm{a}, \mathrm{B}}$ \\
\hline & YF-L904+H9 $\left(1 \times 10^{7}\right)$ & $73.77 \pm 1.31^{\mathrm{a}, \mathrm{BC}}$ & $1.50 \pm 0.25^{\mathrm{a}, \mathrm{BC}}$ & $1.49 \pm 0.17^{\mathrm{a}, \mathrm{A}}$ & $56.87 \pm 0.49^{\mathrm{b}, \mathrm{AB}}$ \\
\hline \multirow[t]{5}{*}{$14 \mathrm{~d}$} & YF-L904 & $46.61 \pm 1.11^{\mathrm{c}, \mathrm{A}}$ & ND & ND & $55.97 \pm 0.37^{\mathrm{c}, \mathrm{C}}$ \\
\hline & YF-L904+H9 $\left(1 \times 10^{6}\right)$ & $49.31 \pm 8.79^{\mathrm{bc}, \mathrm{AB}}$ & $0.33 \pm 0.17^{\mathrm{c}, \mathrm{AB}}$ & $0.34 \pm 0.04^{\mathrm{c}, \mathrm{B}}$ & $67.57 \pm 1.77^{\mathrm{a}, \mathrm{A}}$ \\
\hline & YF-L904+H9 $\left(2 \times 10^{6}\right)$ & $41.86 \pm 3.31^{\mathrm{c}, \mathrm{AB}}$ & $0.49 \pm 0.16^{\mathrm{c}, \mathrm{AB}}$ & $0.35 \pm 0.05^{\mathrm{c}, \mathrm{B}}$ & $55.56 \pm 4.42^{\mathrm{c}, \mathrm{AB}}$ \\
\hline & YF-L904+H9 $\left(5 \times 10^{6}\right)$ & $62.03 \pm 4.75^{\mathrm{b}, \mathrm{B}}$ & $0.80 \pm 0.09^{\mathrm{b}, \mathrm{B}}$ & $0.66 \pm 0.09^{\mathrm{b}, \mathrm{C}}$ & $52.32 \pm 1.81^{\mathrm{d}, \mathrm{D}}$ \\
\hline & YF-L904+H9 $\left(1 \times 10^{7}\right)$ & $78.28 \pm 1.54^{\mathrm{a}, \mathrm{A}}$ & $1.55 \pm 0.02^{\mathrm{a}, \mathrm{B}}$ & $1.08 \pm 0.16^{\mathrm{a}, \mathrm{B}}$ & $61.63 \pm 0.77^{\mathrm{b}, \mathrm{AB}}$ \\
\hline \multirow[t]{5}{*}{$21 \mathrm{~d}$} & YF-L904 & $41.37 \pm 2.00^{\mathrm{c}, \mathrm{B}}$ & ND & ND & $68.39 \pm 0.96^{\mathrm{a}, \mathrm{A}}$ \\
\hline & YF-L904+H9 $\left(1 \times 10^{6}\right)$ & $56.55 \pm 1.60^{\mathrm{b}, \mathrm{A}}$ & $0.60 \pm 0.07^{\mathrm{a}, \mathrm{A}}$ & $0.44 \pm 0.03^{\mathrm{a}, \mathrm{B}}$ & $65.83 \pm 1.41^{\mathrm{ab}, \mathrm{AB}}$ \\
\hline & YF-L904+H9 $\left(2 \times 10^{6}\right)$ & $55.20 \pm 7.09^{\mathrm{b}, \mathrm{A}}$ & $0.38 \pm 0.04^{\mathrm{a}, \mathrm{AB}}$ & $0.57 \pm 0.02^{\mathrm{a}, \mathrm{AB}}$ & $63.74 \pm 1.95^{\mathrm{b}, \mathrm{A}}$ \\
\hline & YF-L904+H9 $\left(5 \times 10^{6}\right)$ & $67.08 \pm 6.43^{\mathrm{ab}, \mathrm{AB}}$ & $0.38 \pm 0.01^{\mathrm{a}, \mathrm{C}}$ & $0.77 \pm 0.02^{\mathrm{a}, \mathrm{BC}}$ & $64.20 \pm 4.15^{\mathrm{b}, \mathrm{B}}$ \\
\hline & YF-L904+H9 $\left(1 \times 10^{7}\right)$ & $73.54 \pm 1.32^{\mathrm{a}, \mathrm{BC}}$ & $0.42 \pm 0.05^{\mathrm{a}, \mathrm{D}}$ & $0.63 \pm 0.05^{\mathrm{a}, \mathrm{C}}$ & $63.84 \pm 0.72^{\mathrm{b}, \mathrm{AB}}$ \\
\hline \multirow[t]{5}{*}{$28 \mathrm{~d}$} & YF-L904 & $40.60 \pm 0.97^{\mathrm{c}, \mathrm{B}}$ & ND & $\mathrm{ND}$ & $62.83 \pm 0.67^{\mathrm{a}, \mathrm{B}}$ \\
\hline & YF-L904+H9 $\left(1 \times 10^{6}\right)$ & $50.39 \pm 1.89^{\mathrm{b}, \mathrm{AB}}$ & $0.51 \pm 0.05^{\mathrm{c}, \mathrm{A}}$ & $0.63 \pm 0.15^{\mathrm{c}, \mathrm{A}}$ & $63.58 \pm 5.05^{\mathrm{a}, \mathrm{B}}$ \\
\hline & YF-L904+H9 $\left(2 \times 10^{6}\right)$ & $36.46 \pm 2.43^{\mathrm{c}, \mathrm{B}}$ & $0.33 \pm 0.08^{\mathrm{c}, \mathrm{B}}$ & $0.28 \pm 0.02^{\mathrm{b}, \mathrm{B}}$ & $64.94 \pm 2.22^{\mathrm{a}, \mathrm{AB}}$ \\
\hline & YF-L904+H9 $\left(5 \times 10^{6}\right)$ & $74.83 \pm 0.92^{\mathrm{a}, \mathrm{A}}$ & $1.51 \pm 0.28^{\mathrm{b}, \mathrm{A}}$ & $1.33 \pm 0.03^{\mathrm{a}, \mathrm{A}}$ & $71.28 \pm 1.55^{\mathrm{a}, \mathrm{A}}$ \\
\hline & YF-L904+H9 $\left(1 \times 10^{7}\right)$ & $76.72 \pm 1.60^{\mathrm{a}, \mathrm{AB}}$ & $1.89 \pm 0.18^{\mathrm{a}, \mathrm{A}}$ & $1.43 \pm 0.04^{\mathrm{a}, \mathrm{A}}$ & $71.13 \pm 2.89^{\mathrm{a}, \mathrm{A}}$ \\
\hline
\end{tabular}

\footnotetext{
${ }^{a-e}$ Different lowercase superscript letters indicate differences $(P<0.05)$ between samples of different treatments at the same time point.

${ }^{\mathrm{A}-\mathrm{D}}$ Different uppercase superscript letters indicate differences $(P<0.05)$ between samples of the same treatment at different time points.

${ }^{1}$ YF-L904 and H9 represent the commercial starter and Lactobacillus helveticus H9, respectively. Data are expressed in mean \pm SD.

${ }^{2}$ Not detected.
} 
15 major flavors, including acetic acid, 2-pentanone, acetoin, 1-pentanol, pentanal, 1-hexanol, 2-heptanone, heptanal, methoxyphenyloxime, benzaldehyde, hexanoic acid, 2-nonen-1-ol, 2-nonanone, nonanal, and 2-undecanone, were identified across all samples with or without L. helveticus H9. The composition of the major volatile flavor compounds is summarized in Supplemental Table S2 (https://doi.org/10.3168/jds.2018-14602).

We further analyzed the volatile flavor compound profiles with PCA; PC1 and PC2 accounted for 42.46 and $22.22 \%$ of the total variance, respectively (Figure $6)$. Figure 6 a grouped the samples based on the starter bacteria used. Symbols representing the control group (without H9) were separated from those representing the L. helveticus H9-containing fermented milks, suggesting distinct volatile flavor compounds profiles between yogurts fermented with and without $L$. helveticus $\mathrm{H} 9$; the existence of significant differences was also confirmed by MANOVA $(P<0.05$; Figure $6 \mathrm{a}, 6 \mathrm{c})$. The volatile flavor compounds pentanal and benzaldehyde correlated most with PC1, whereas 2-heptanone and 2-nonanone correlated strongly with PC2. In particular, fermented milks produced with the commercial starter and L. helveticus $\mathrm{H} 9$ were characterized by higher levels a

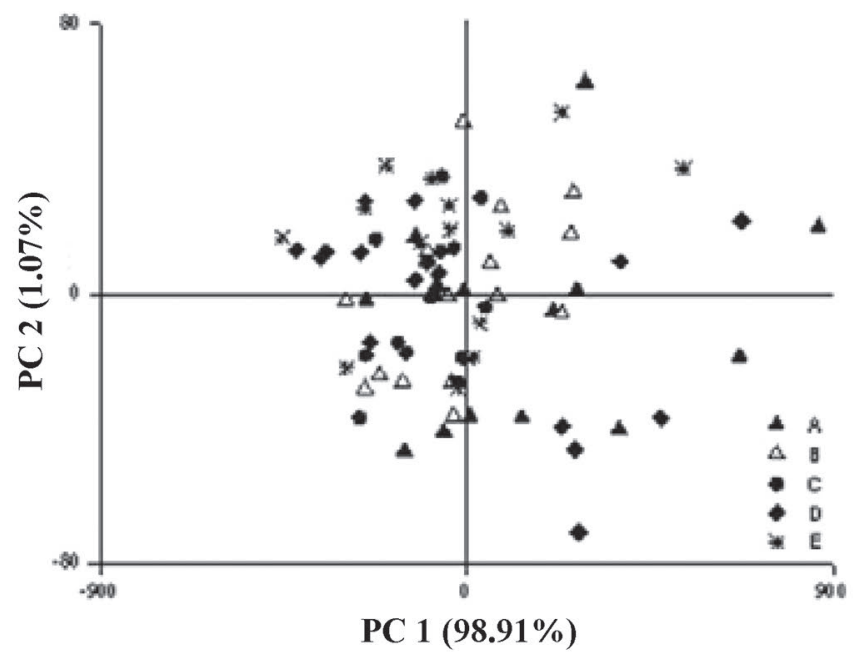

C

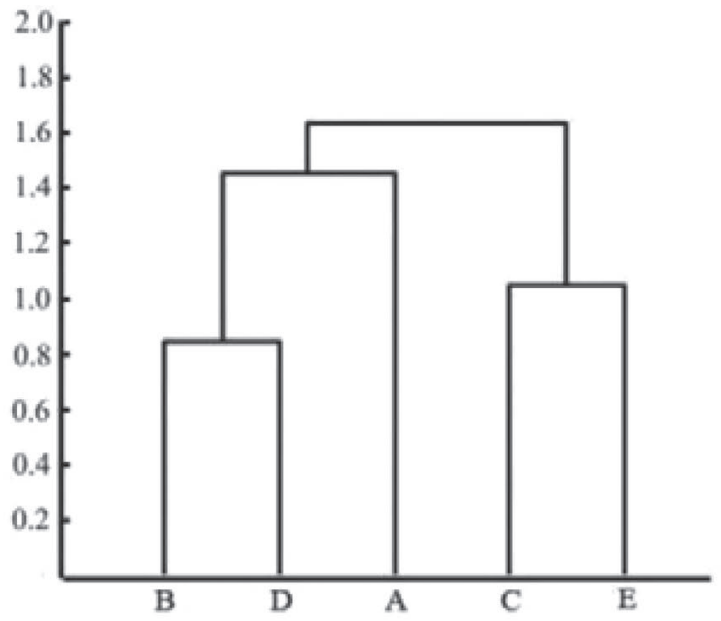

b
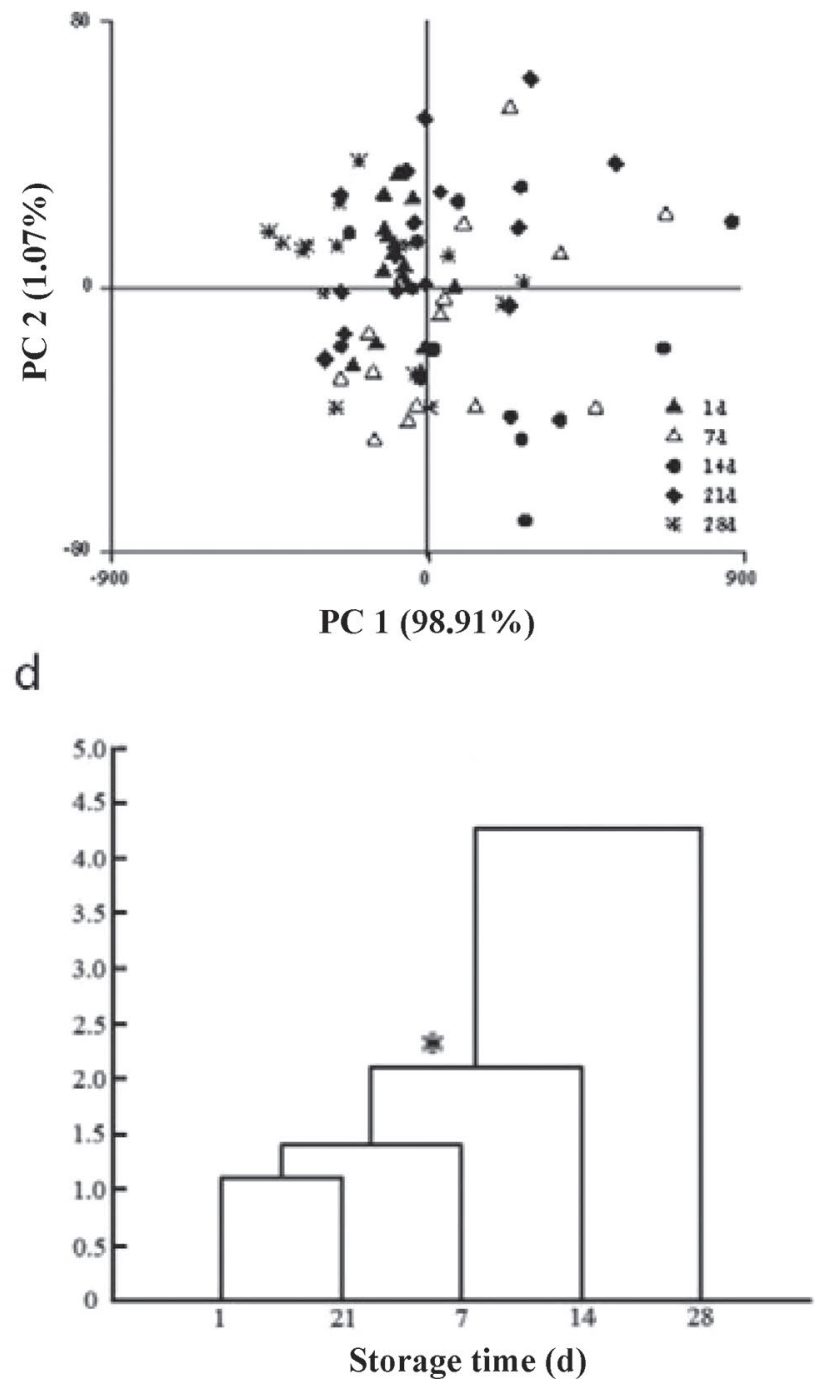

Figure 5. Principal component (PC) analysis and multivariate ANOVA of fermented milk texture profile. Samples were grouped by inoculum size of Lactobacillus helveticus H9 used (a, c) and storage duration (b, d). Each symbol represents the data set of one sample. In panel a, A = fermented milk without L. helveticus H9 as control; B = fermented milk with commercial starter culture (YF-L904) and L. helveticus H9 (1 $\times$ $\left.10^{6} \mathrm{cfu} / \mathrm{mL}\right) ; \mathrm{C}=$ fermented milk with YF-L904 and L. helveticus $\mathrm{H} 9\left(2 \times 10^{6} \mathrm{cfu} / \mathrm{mL}\right) ; \mathrm{D}=$ fermented milk with YF-L904 and L. helveticus H9 $\left(5 \times 10^{6} \mathrm{cfu} / \mathrm{mL}\right) ; \mathrm{E}=$ fermented milk with YF-L904 and L. helveticus $\mathrm{H} 9\left(1 \times 10^{7} \mathrm{cfu} / \mathrm{mL}\right)$. In panel b, the fermented milks were stored cold for $1,7,14,21$, and $28 \mathrm{~d}$. In panels $\mathrm{c}$ and $\mathrm{d}$, the Mahalanobis distance between group means was used for cluster analysis $(* P<0.05)$. 
a

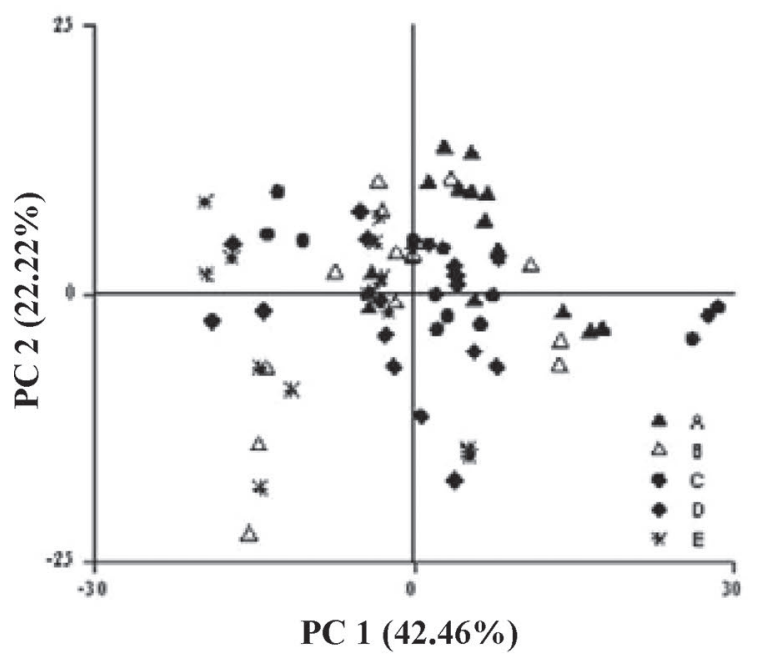

C

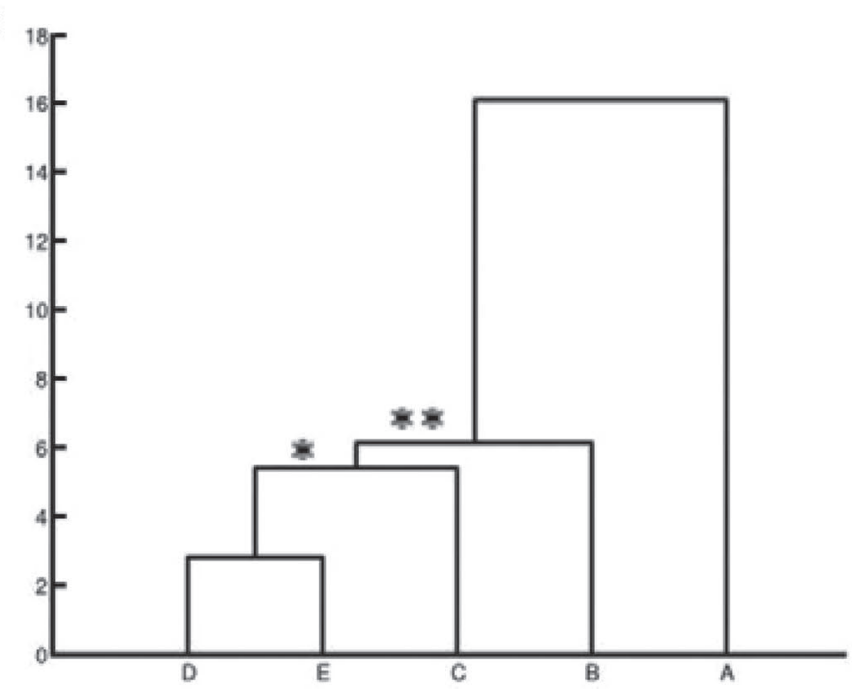

b
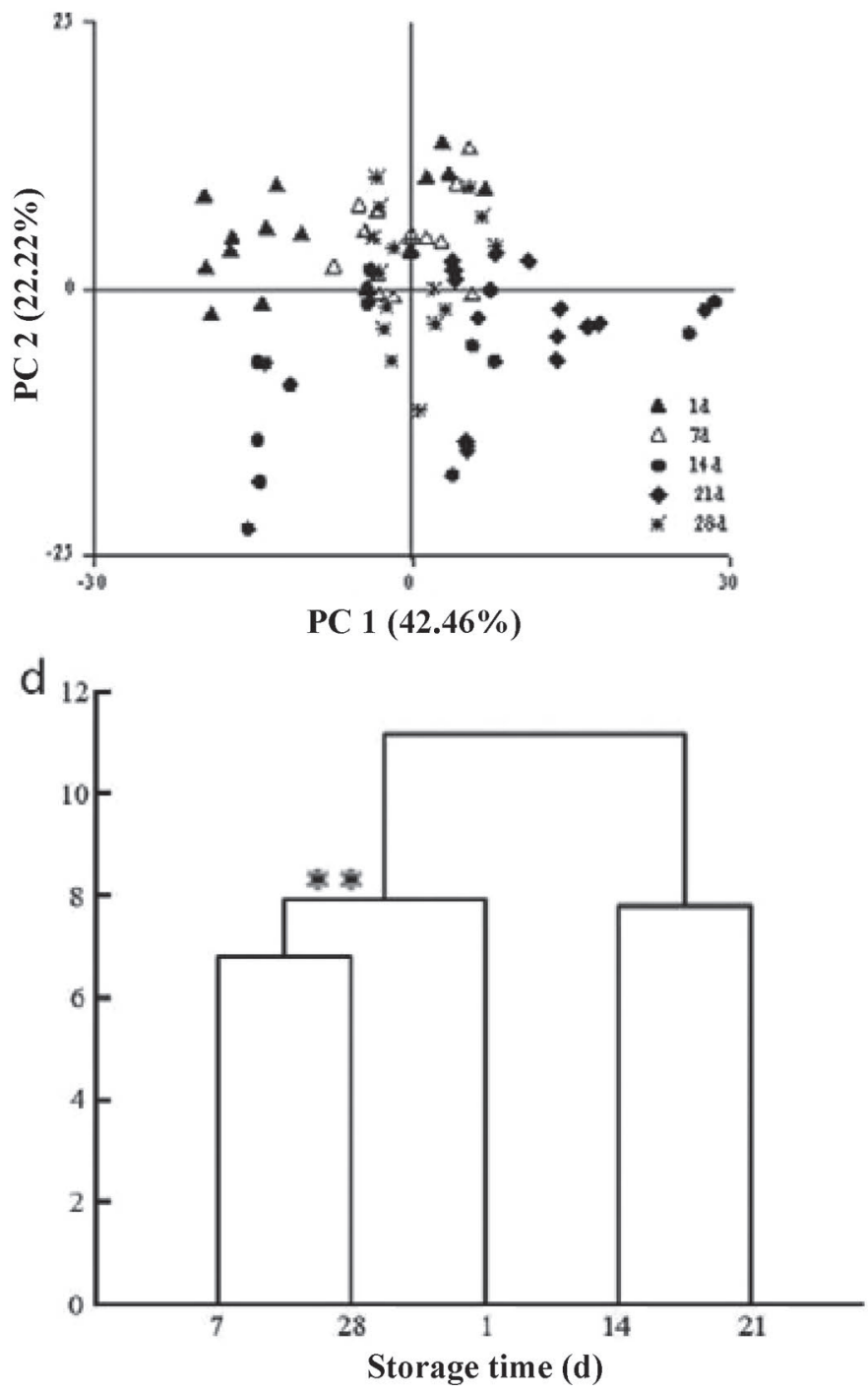

Figure 6. Principal component (PC) analysis and multivariate ANOVA of fermented milk volatile flavor compounds. Samples were grouped by inoculum size of Lactobacillus helveticus $\mathrm{H} 9$ used (a, c) and storage duration (b, d). Each symbol represents the data set of one sample. In panel a, A = fermented milk without L. helveticus $\mathrm{H} 9$ as control; B = fermented milk with commercial starter culture (YF-L904) and L. helveticus $\mathrm{H} 9\left(1 \times 10^{6} \mathrm{cfu} / \mathrm{mL}\right) ; \mathrm{C}=$ fermented milk with YF-L904 and L. helveticus $\mathrm{H} 9\left(2 \times 10^{6} \mathrm{cfu} / \mathrm{mL}\right) ; \mathrm{D}=$ fermented milk with YF-L904 and L. helveticus $\mathrm{H} 9\left(5 \times 10^{6} \mathrm{cfu} / \mathrm{mL}\right) ; \mathrm{E}=$ fermented milk with YF-L904 and L. helveticus $\mathrm{H} 9\left(1 \times 10^{7} \mathrm{cfu} / \mathrm{mL}\right)$. In panel b, the fermented milk was stored cold for $1,7,14,21$, and 28 d. In panels $\mathrm{c}$ and $\mathrm{d}$, the Mahalanobis distance between group means was used for the cluster analysis $\left({ }^{*} P<0.05,{ }^{* *} P<0.01\right)$.

of 2-nonanone, 2-undecanone, and acetoin (except for the samples stored for $14 \mathrm{~d})$. Meanwhile, the content of acetic acid increased significantly $(P<0.05)$ compared with the control group produced only with the commercial starter.

On the PCA score plot grouped with storage time (Figure 6b), some overlapping was observed between sample groups stored for different times; however, the MANOVA results revealed the existence of significant differences between groups (Figure 6d; $P<0.05$ ).

\section{Sensory Evaluation of Fermented Milks}

Results from the sensory evaluation of the fermented milks based on the attributes of appearance, flavor, and texture are presented in a spider plot (Figure 7). No significant difference was observed in overall acceptability during early time phase (d 1 and 14) of cold storage between all groups $(P>0.05)$. The scores for flavor, texture, and appearance generally decreased slightly over the storage period. Flavor and texture 


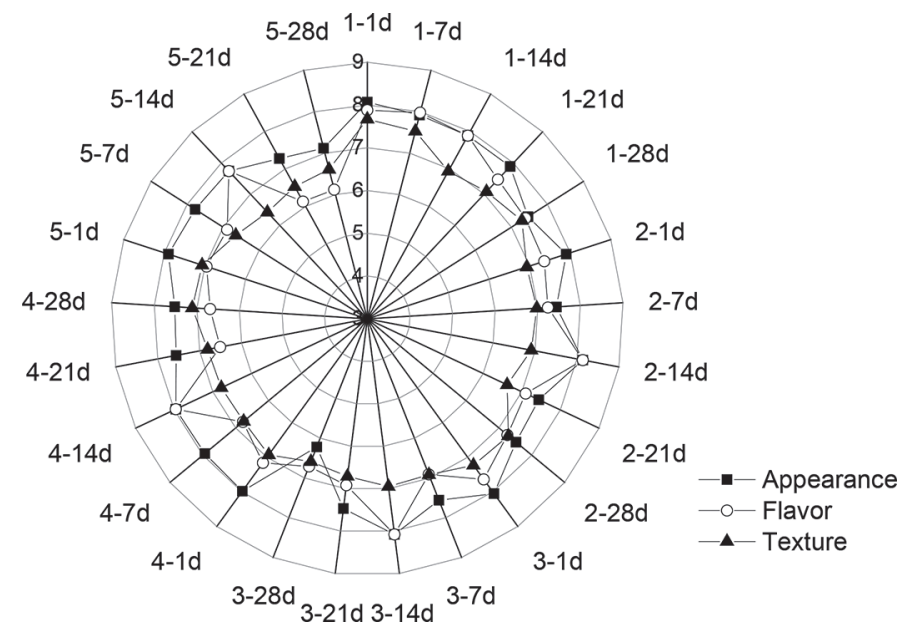

Figure 7. Spider plot showing changes in the appearance, flavor, and texture of fermented milks during cold storage. $1=$ fermented milk without Lactobacillus helveticus H9 as control; 2 = fermented milk with commercial starter culture (YF-L904) and L. helveticus $\mathrm{H} 9$ $\left(1 \times 10^{6} \mathrm{cfu} / \mathrm{mL}\right) ; 3=$ fermented milk with YF-L904 and L. helveticus H9 $\left(2 \times 10^{6} \mathrm{cfu} / \mathrm{mL}\right) ; 4=$ fermented milk with YF-L904 and $L$. helveticus $\mathrm{H} 9\left(5 \times 10^{6} \mathrm{cfu} / \mathrm{mL}\right) ; 5=$ fermented milk with YF-L904 and L. helveticus H9 $\left(1 \times 10^{7} \mathrm{cfu} / \mathrm{mL}\right)$. The fermented milk was stored in the cold for 1, 7, 14, 21, and 28 d. Rings 3 to 9 indicate sensory evaluation scores.

scores were lower in the L. helveticus H9-containing fermented milks than in the control after storage for 7 , 21 , and $28 \mathrm{~d}(P<0.05)$. However, flavor scores of the L. helveticus $\mathrm{H} 9$ milks increased compared with control at d 14. In general, the inoculum of L. helveticus $\mathrm{H} 9 \mathrm{did}$ not change the sensory quality (appearance, flavor, and texture) significantly during cold storage $(P>0.05$; Supplemental Table S3; https://doi.org/10.3168/jds .2018-14602).

\section{DISCUSSION}

Lactobacillus helveticus is increasingly applied in functional dairy products because of its potential antihypertensive effect. However, when probiotic adjunct cultures are used in developing novel dairy products, it is important to consider their effect on the product characteristics, quality, and ultimate acceptability to consumers. Our study investigated whether and how $L$. helveticus $\mathrm{H} 9$ affected product storage stability in milk fermentation.

The adjunct use of L. helveticus H9 with the commercial starter strain (YF-L904) significantly reduced fermentation time, most likely because of the high proteolytic capacity of L. helveticus H9. A higher level of $\alpha$-amino groups was observed in the cold-stored H9fermented milks, indicating an increased level of nitrogenous compounds. Proteinases and peptidases are the major proteolytic enzymes responsible for the release of amino acids and nitrogen (Parmar et al., 2017). Enhanced survival of yogurt bacteria could be reflected by the post-acidification as storage prolonged. Although post-acidification may confer specific product taste and flavor, significant post-acidification may compromise a product's sensory quality. Some fermented milk starter bacteria naturally possess strong post-acidification activity; for example, Streptococcus thermophilus TA040 and L. delbrueckii ssp. bulgaricus LB340 (Damin et al., 2008). The post-acidification of H9-fermented milks (especially with inocula of $5 \times 10^{6}$ and $1 \times 10^{7} \mathrm{cfu} /$ $\mathrm{mL}$ ) might have been related to the H9 inoculum and storage duration.

Lactate is the major acid produced as a by-product together with other organic acids during the hydrolysis of lactose into glucose and galactose (Costa et al., 2013). The use of L. helveticus H9 increased lactate and acetate contents but decreased citrate content, which was also seen when other lactic acid bacteria were used, such as Lactobacillus plantarum (de Figueroa et al., 1996) and L. helveticus ATCC 15807 (Torino et al., 2005). Citric acid is an intermediate of the tricarboxylic acid cycle, which is produced from glucose through the glycolytic pathway and oxidative conversion of pyruvic acid into acetyl-CoA by pyruvate dehydrogenase ( $\mathrm{Lu}$ et al., 2018). However, the concentration of citrate increased after $1 \mathrm{~d}$ of storage, perhaps due to the excessive pyruvic acid accumulated during milk fermentation, which was progressively metabolized into citrate at the beginning of the cold storage. These compounds contribute to flavor development and they may serve as natural preservatives to extend product shelf life (Ilicic et al., 2017).

Fermented milks produced by L. helveticus H9 possessed strong ACEI activity and contained the antihypertensive peptides IPP and VPP (Chen et al., 2014b). A large inoculum size of $L$. helveticus H9 $\left(1 \times 10^{7} \mathrm{cfu} /\right.$ $\mathrm{mL}$ ) resulted in high and stable fermented milk ACEI activity of $70.47 \%$ (vs. $3.10 \%$ for the control after $1 \mathrm{~d}$ of cold storage). The concentrations of VPP $(\mathrm{r}=0.74)$ and IPP $(\mathrm{r}=0.78)$ but not GABA were correlated with the ACEI activity. Moreover, the VPP and IPP peptides were exclusively detected in H9-fermented milk, probably because of the intrinsic lack of proteolytic enzyme activity in the commercial strains. These results suggest that the antihypertensive effect of $L$. helveticus $\mathrm{H} 9$ is most likely attributed to peptides such as IPP and VPP but not GABA, although all have been reported to be antihypertensive in previously published human or animal trial experiments (Donkor et al., 2007; Sun et al., 2008; Şanli et al., 2016). Some Lactobacillus species, of starter or nonstarter origin, contribute to the production of peptides with ACEI activity in dairy products (Chaves-López et al., 2014; 
Solieri et al., 2015). The amount of ACE inhibitors released depends on the stage of fermentation. However, excessive proteolysis could decrease ACEI activity in fermented dairy products.

Some lactic acid bacteria species, such as Streptococcus thermophilus, L. delbrueckii ssp. bulgaricus, Lactobacillus acidophilus, and L. helveticus, have shown positive effects on the organoleptic properties of fermented products; for example, flavor and texture (Moslehishad et al., 2013; Bristone et al., 2016). Here, the overall quality of all samples was evaluated by PCA and MANOVA, and the results showed that the fermented milk of low H9 inoculum $\left(5 \times 10^{6} \mathrm{cfu} / \mathrm{mL}\right)$ and the control fermented solely with commercial strains were most similar in the monitored sensory properties. Adding $L$. helveticus $\mathrm{H} 9$ likely increased the small molecule proteins in the fermented milk and its viscosity during the first $14 \mathrm{~d}$ of storage. The increase in viscosity might be related to extracellular polysaccharides produced by the bacteria. Moreover, the low $\mathrm{pH}$ and temperature conditions could promote protein coagulation and gel formation (da Silva Fernandes et al., 2017).

Over 400 volatile compounds have been identified in the process of milk fermentation by lactic acid bacteria (Walstra and Jenness, 1984). We detected over 100 different volatile metabolites, and gradual changes were observed in the volatile flavor compound profile throughout cold storage. Acetoin is a universal flavor substance present in many fermented dairy products; it has a mild creamy, slightly sweet, and butter-like flavor similar to that of diacetyl (Roncal et al., 2017). All L. helveticus H9-containing fermented milks had more acetoin than the control milk during cold storage. However, L. helveticus H9 lacks the 2 major acetoin-synthesizing enzymes, $\alpha$-acetolactate synthase and $\alpha$-acetolactate decarboxylase, in its genome. Thus, acetoin was likely released by the commercial starter bacteria, while the acetoin-synthesizing pathway was enhanced by L. helveticus H9; the mechanism for this has yet to be identified. The compounds 2-heptanone, 2-nonanone, and 2-undecanone contribute to the stale, cardboard, or metallic flavor in UHT milk (Moio et al., 1994). We observed relatively high contents of 2-heptanone and 2-nonanone in all fermented milks before $21 \mathrm{~d}$ of storage (Supplemental Table S2; https: //doi.org/10.3168/jds.2018-14602). Among the volatile flavor compounds, benzaldehyde was detected exclusively in L. helveticus H9-containing fermented milks. This compound plays a key role in the yogurt flavor in fermented milk (Benozzi et al., 2015). It might have been produced from fatty acid oxidation including the $\alpha$-oxidation of phenyl acetaldehyde or $\beta$-oxidation of cinnamic acid (Casey and Dobb, 1992; Sieber et al., 1995). Thus, our results showed that adding $L$. helveti- cus H9 did change the volatile flavor compound profile during storage, although this might not be considered a negative effect.

No significant difference was found in appearance, flavor, and texture early in the storage period of the fermented milks. However, as storage continued, the sensory scores of the H9-containing fermented milks were significantly lower than that of the control. The lower scores were mainly attributed to changes in flavor and texture but not appearance. Flavor scores were negatively correlated with volatile flavor ketones $(\mathrm{r}=$ -0.69 ) but positively correlated with aldehydes ( $\mathrm{r}=$ 0.59 ). These metabolite changes could be attributed to the activity of live bacteria in the yogurt, particularly L. helveticus H9. Our results show that L. helveticus H9 supplementation did alter the sensory quality of fermented milk beyond 2 wk of storage. Therefore, it is necessary to carefully consider the product's shelf life, inoculum of $L$. helveticus $\mathrm{H} 9$, and milk ingredients to maximize product stability.

\section{CONCLUSIONS}

Our work investigated the effect of using $L$. helveticus $\mathrm{H} 9$ as an adjunct starter bacterium in yogurt fermentation and storage. Inclusion of L. helveticus $\mathrm{H} 9$ offered various advantages in milk fermentation compared with the control, which was fermented solely by commercial starter bacteria, including shortening of fermentation time and an increased richness of volatile flavor compounds, particularly benzaldehyde and acetoin. Most importantly, the fermented milk antihypertensive peptides VPP and IPP were exclusively found in H9-fermented milks, and they were stable during cold storage. Although L. helveticus H9-supplemented fermented milks had lower sensory scores than the control, especially beyond 2 wk of cold storage, the strain carries good potential to be applied in functional dairy products.

\section{ACKNOWLEDGMENTS}

This study was in part supported by the National Natural Science Foundation of China (Beijing; grant no. 31571814). The authors report no conflict of interest, and this work contains no clinical study or patient data.

\section{REFERENCES}

Ahtesh, F. B., L. Stojanovska, and V. Apostolopoulos. 2017. Processing and sensory characteristics of a fermented low-fat skim milk drink containing bioactive antihypertensive peptides, a functional milk product. Int. J. Dairy Technol. 70:1-10. https://doi.org/10 .1111/1471-0307.12479.

Journal of Dairy Science Vol. 102 No. 1, 2019 
Airidengcaicike, X. Chen, X. Du, W. Wang, J. Zhang, Z. Sun, W. Liu, L. Li, T. Sun, and H. Zhang. 2010. Isolation and identification of cultivable lactic acid bacteria in traditional fermented milk of Tibet in China. Int. J. Dairy Technol. 63:437-444.

Barrantes, E., A. Y. Tamime, and A. M. Sword. 1994. Production of low calorie yogurt using skim milk powder and fat-substitute. 3. Microbiological and organoleptic qualities. Milchwissenschaft 49:205-208.

Bayarri, S., I. Carbonell, E. X. Barrios, and E. Costell. 2011. Impact of sensory differences on consumer acceptability of yoghurt and yoghurt-like products. Int. Dairy J. 21:111-118.

Beermann, C., and J. Hartung. 2013. Physiological properties of milk ingredients released by fermentation. Food Funct. 4:185-199.

Benozzi, E., A. Romano, V. Capozzi, S. Makhoul, L. Cappellin, I. Khomenko, E. Aprea, M. Scampicchio, G. Spano, T. D. Mark, F. Gasperi, and F. Biasioli. 2015. Monitoring of lactic fermentation driven by different starter cultures via direct injection mass spectrometric analysis of flavour-related volatile compounds. Food Res. Int. 76:682-688.

Bian, X., S. E. Evivie, Z. Muhammad, G. W. Luo, H. Z. Liang, N. N. Wang, and G. C. Huo. 2016. In vitro assessment of the antimicrobial potentials of Lactobacillus helveticus strains isolated from traditional cheese in Sinkiang China against food-borne pathogens. Food Funct. 7:789-797.

Bristone, C., E. C. Igwe, M. H. Badau, O. Boafo, and V. G. Zira. 2016. Microbial ecology and effectiveness of different starter cultures in yoghurts produced from whole cow milk and soybeans. Afr. J. Food Sci. Technol. 7:107-117.

Casey, J., and R. Dobb. 1992. Microbial routes to aromatic aldehydes. Enzyme Microb. Technol. 14:739-747.

Chaves-López, C., A. Serio, A. Paparella, M. Martuscelli, A. Corsetti, R. Tofalo, and G. Suzzi. 2014. Impact of microbial cultures on proteolysis and release of bioactive peptides in fermented milk. Food Microbiol. 42:117-121.

Chen, Y., W. Liu, J. Xue, J. Yang, X. Chen, Y. Shao, L. Y. Kwok, M. Bilige, L. Mang, and H. Zhang. 2014a. Angiotensin-converting enzyme inhibitory activity of Lactobacillus helveticus strains from traditional fermented dairy foods and antihypertensive effect of fermented milk of strain H9. J. Dairy Sci. 97:6680-6692.

Chen, Y., Z. Wang, X. Chen, Y. Liu, H. Zhang, and T. Sun. 2010. Identification of angiotensin I-converting enzyme inhibitory peptides from koumiss, a traditional fermented mare's milk. J. Dairy Sci. 93:884-892.

Chen, Y. F., W. J. Zhao, R. N. Wu, Z. H. Sun, W. Y. Zhang, J. C. Wang, M. Bilige, and H. P. Zhang. 2014b. Proteome analysis of Lactobacillus helveticus H9 during growth in skim milk. J. Dairy Sci. 97:7413-7425.

Church, F. C., H. E. Swaisgood, D. H. Porter, and G. L. Catignani. 1983. Spectrophotometric assay using o-phthaldialdehyde for determination of proteolysis in milk and isolated milk proteins. J. Dairy Sci. 66:1219-1227.

Costa, M. P., C. F. Balthazar, R. V. B. P. Moreira, A. C. Gomes, and C. A. Conte-Júnior. 2013. Fermented milk: Potential functional food. Enciclopedia Biosfera 9:1387-1408.

Damin, M. R., E. Minowa, M. R. Alcantara, and M. N. Oliveira. 2008. Effect of cold storage on culture viability and some rheological properties of fermented milk prepared with yogurt and probiotic bacteria. J. Texture Stud. 39:40-55.

da Silva Fernandes, M., F. S. Lima, D. Rodrigues, C. Handa, M. Guelfi, S. Garcia, and E. I. Ida. 2017. Evaluation of the isoflavone and total phenolic contents of kefir-fermented soymilk storage and after the in vitro, digestive system simulation. Food Chem. 229:373-380.

de Figueroa, R. M., I. L. Benito de Cardenas, F. Sesma, F. Alvarez, A. P. de Ruiz Holgado, and G. Oliver. 1996. Inducible transport of citrate in Lactobacillus rhamnosus ATCC 7469. J. Appl. Bacteriol. $81: 348-354$.

Donkor, O. N., A. Henriksson, T. Vasiljevic, and N. P. Shah. 2007. Proteolytic activity of dairy lactic acid bacteria and probiotics as determinant of growth and in vitro angiotensin-converting enzyme inhibitory activity in fermented milk. Dairy Sci. Technol. 87:21-38.
El-Fattah, A. A., S. Sakr, S. El-Dieb, and H. Elkashef. 2016. Angiotensin-converting enzyme inhibition and antioxidant activity of commercial dairy starter cultures. Food Biotechnol. 25:1745-1751.

FAO/WHO. 2002. Guidelines for the evaluation of probiotics in food. Report of a joint FAO/ WHO working group on drafting guidelines for the evaluation of probiotics in food. Food and Agriculture Organization of the United Nations, Rome, Italy, and World Health Organization, Geneva, Switzerland.

Foster, L. M., T. Tompkins, and W. Dahl. 2011. A comprehensive post-market review of studies on a probiotic product containing Lactobacillus helveticus R0052 and Lactobacillus rhamnosus R0011. Benef. Microbes 2:319-334.

Griffiths, M. W., and A. M. Tellez. 2013. Lactobacillus helvictus: The proteolytic system. Front. Microbiol. 4:1-9.

Hussain, M., F. R. Awan, A. Gujjar, S. Hafeez, and M. Islam. 2018. A case control association study of ACE gene polymorphism (I/D) with hypertension in Punjabi population from Faisalabad, Pakistan. Clin. Exp. Hypertens. 40:186-191.

Ilicic, M., S. Milanovic, K. Kanuric, V. Vukic, S. Popovic, and D. Vukic. 2017. Content of sugar, organic acids and ethanol in fermented milk beverages obtained with different types of Kombucha inoculum. Acta Period. Technol. 48:109-116.

Jauhiainen, T., H. Vapaatalo, T. Poussa, S. Kyronpalo, M. Rasmussen, and R. Korpela. 2005. Lactobacillus helveticus fermented milk lowers blood pressure in hypertensive subjects in 24-h ambulatory blood pressure measurement. Am. J. Hypertens. 18:1600-1605.

Li, C., W. Li, X. Chen, M. Feng, X. Rui, M. Jiang, and M. Dong. 2014. Microbiological, physicochemical and rheological properties of fermented soymilk produced with exopolysaccharide (EPS) producing lactic acid bacteria strains. Lebensm. Wiss. Technol. $57: 477-485$.

Li, J., Q. Hou, J. Zhang, H. Xu, Z. Sun, B. Menghe, and H. Zhang. 2017. Carbohydrate staple food modulates gut microbiota of Mongolians in China. Front. Microbiol. 8:484. https://doi.org/10.3389/ fmicb.2017.00484.

Lu, Y., H. Ishikawa, Y. Kwon, F. Hu, T. Miyakawa, and M. Tanokura 2018. Real-time monitoring of chemical changes in three kinds of fermented milk products during fermentation using quantitative difference NMR spectroscopy. J. Agric. Food Chem. 66:1479-1487.

Maeno, M., N. Yamamoto, and T. Takano. 1996. Identification of an antihypertensive peptide from casein hydrolysate produced by a proteinase from Lactobacillus helveticus CP790. J. Dairy Sci. 79:1316-1321.

Moio, L., P. Etievant, D. Langlois, and J. Dekimpe. 1994. Detection of powerful odorants in heated milk by use of extract dilution sniffing analysis. J. Dairy Res. 61:385-394.

Moslehishad, M., S. Mirdamadi, M. R. Ehsani, H. Ezzatpanah, and A. A. Moosavi-Movahedi. 2013. The proteolytic activity of selected lactic acid bacteria in fermenting cow's and camel's milk and the resultant sensory characteristics of the products. Int. J. Dairy Technol. 66:279-285.

National Standards of the People's Republic of China. 2010. National Food Safety Standard of Fermented Milk. GB 19302-2010. China National Standards, Beijing, China.

National Standards of the People's Republic of China. 1996. Method for analysis of hygienic standard of milk and milk products. Bulletin 5009:46. China National Standards, Beijing, China.

Nielsen, M. S., T. Martinussen, B. Flambard, K. I. Sørensen, and J. Otte. 2009. Peptide proles and angiotensin-I-converting enzyme inhibitory activity of fermented milk products: Effect of bacterial strain, fermentation $\mathrm{pH}$, and storage time. Int. Dairy J. 19:155165.

Pan, D. D., Z. Wu, T. Peng, X. Q. Zeng, and H. Li. 2014. Volatile organic compounds profile during milk fermentation by Lactobacillus pentosus and correlations between volatiles flavor and carbohydrate metabolism. J. Dairy Sci. 97:624-631.

Parmar, H., S. Hati, and A. Sakure. 2017. In vitro and in silico analysis of novel ACE-inhibitory bioactive peptides derived from fermented goat milk. Int. J. Pept. Res. Ther. 24:441-453.

Roncal, T., S. Caballero, M. Guereñu, I. Rincón, S. Prieto-Fernández, and J. R. Ochoa-Gómez. 2017. Efficient production of acetoin by 
fermentation using the newly isolated mutant strain Lactococcus lactis ssp. lactis CML B4. Process Biochem. 58:35-41.

Şanli, T., H. C. Akal, A. Yetişemiyen, and A. A. Hayaloglu. 2016. Influence of adjunct cultures on angiotensin-converting enzyme (ACE)-inhibitory activity, organic acid content and peptide profile of kefir. Int. J. Dairy Technol. 71:131-139. https://doi.org/10 1111/1471-0307.12346

Scherer, R., A. C. P. Rybka, C. A. Ballus, A. D. Meinhart, J. T. Filho, and H. T. Godoy. 2012. Validation of a HPLC method for simultaneous determination of main organic acids in fruits and juices. Food Chem. 135:150-154.

Seppo, L., T. Jauhiainen, T. Poussa, and R. Korpela. 2003. A fermented milk high in bioactive peptides has a blood pressure-lowering effect in hypertensive subjects. Am. J. Clin. Nutr. 77:326-330.

Seppo, L., O. Kerojoki, T. Suomalainen, and R. Korpela. 2002. The effect of a Lactobacillus helveticus LBK-16 H fermented milk on hypertension-A pilot study on humans. Milchwissenschaft $57: 124-127$.

Sfakianakis, P., and C. Tzia. 2014. Conventional and innovative processing of milk for yogurt manufacture; development of texture and flavor: A review. Foods 3:176-193.

Sieber, R., U. Butikofer, and J. O. Bosset. 1995. Benzoic acid as a natural compound in cultured dairy products and cheese. Int. Dairy J. 5:227-246.

Solieri, L., G. S. Rutella, and D. Tagliazucchi. 2015. Impact of nonstarter lactobacilli on release of peptides with angiotensin-converting enzyme inhibitory and antioxidant activities during bovine milk fermentation. Food Microbiol. 51:108-116.

Sun, T., S. Zhao, H. Wang, C. Cai, Y. Chen, and H. Zhang. 2008. ACE-inhibitory activity and gamma-aminobutyric acid content of fermented skim milk by Lactobacillus helveticus isolated from Xinjiang koumiss in China. Eur. Food Res. Technol. 228:607-612.

Supavititpatana, P., T. I. Wirjantoro, A. Apichartsrangkoon, and P. Raviyan. 2008. Addition of gelatin enhanced gelation of corn-milk yogurt. Food Chem. 106:211-216.
Torino, M. I., M. P. Taranto, and G. F. D. Valdez. 2005. Citrate catabolism and production of acetate and succinate by Lactobacillus helveticus ATCC 15807. Appl. Microbiol. Biotechnol. 69:79-85.

Tripathi, M. K., and S. K. Giri. 2014. Probiotic functional foods: Survival of probiotics during processing and storage. J. Funct. Foods 9:225-241.

Walstra, B. P., and R. Jenness. 1984. Dairy Chemistry and Physics. Wiley, New York, NY.

Wang, J., C. Li, J. Xue, J. Yang, Q. Zhang, H. Zhang, and Y. Chen. 2015. Fermentation characteristics and angiotensin I-converting enzyme-inhibitory activity of Lactobacillus helveticus isolate H9 in cow milk, soy milk, and mare milk. J. Dairy Sci. 98:3655-3664.

Wang, J. C., Z. Guo, Q. Zhang, L. Yan, Y. F. Chen, X. Chen, X. M. Liu, W. Chen, and H. P. Zhang. 2009. Effect of probiotic Lactobacillus casei Zhang on fermentation characteristics of set yogurt. Int. J. Dairy Technol. 63:105-112.

Wu, J., R. E. Aluko, and A. D. Muir. 2002. Improved method for direct high-performance liquid chromatography assay of angiotensin-converting enzyme-catalyzed reactions. J. Chromatogr. A 950:125-130.

Wu, H., G. J. Hulbert, and J. R. Mount. 2000. Effects of ultrasound on milk homogenization and fermentation with yogurt starter. Innov. Food Sci. Emerg. Emerg. Technol. 1:211-218.

Yamamoto, N., A. Akino, and T. Takano. 1994. Antihypertensive effect of the peptides derived from casein by an extracellular proteinase from Lactobacillus helveticus CP790. J. Dairy Sci. 77:917.

Yang, Y. J., and B. S. Sheu. 2012. Probiotics-containing yogurts suppress Helicobacter pylori load and modify immune response and intestinal microbiota in the Helicobacter pylori-infected children. Helicobacter 17:297-304.

Zoumpopoulou, G. 2016. Production of bioactive peptides and probiotic potential of lactic acid bacteria isolated from traditional Greek dairy products. Pages 2-26 in Megaron Athens International Conference Center. Athens, Greece. 